\title{
Pengaruh Reward, Disiplin Kerja dan Komunikasi terhadap Kepuasan Kerja di PT. Kerta Rajasa Raya Mojokerto
}

\author{
*Aris Affandi, Cholifah, Indah Noviandari \\ Program Studi Manajemen Fakultas Ekonomi dan Bisnis \\ Universitas Bhayangkara Surabaya, Indonesia
}

DOI: $10.46821 /$ benchmark.v2i1.220

\begin{abstract}
Abstrak
Penelitian ini bertujuan untuk mengetahui pengaruh reward, disiplin kerja dan komunikasi terhadap kepuasan kerja di PT. Kerta Rajasa Raya Mojokerto. Jenis penelitian yang digunakan dalam penelitian ini adalah pendekatan kuantitatif. Populasi dalam penelitian ini adalah seluruh karyawan PT.Kerta Rajasa Raya Mojokerto dengan jumlah sampel yang diambil sebanyak 83 karyawan. Teknik pengambilan sampel yang digunakan adalah simple random sampling dengan teknik pengumpulan data menggunakan kuesioner. Teknik analisis data yang digunakan adalah analisis regresi linear berganda dengan menggunakan Uji F, Uji T serta Uji Dominan dengan taraf signifikan 10\% melalui Statistical Package for the Social Science (SPSS). Hasil pengujian ini menunjukkan bahwa variabel bebasreward, disiplin kerja dan komunikasi secara simultan berpengaruh signifikan dengan hasil regresi linier berganda dalam uji $\mathrm{F}$ dipe roleh $\mathrm{F}_{\text {hitung }}$ sebesar 50.713lebih besar dari $F_{\text {tabel }}$ sebesar 2,72 sedangkan pengaruh secara parsial berpengaruh signifikan melalui uji t diperoleh $\mathrm{t}_{\text {hitung }}$ untuk masing-masing variabel bebas yaitu $\mathrm{t}_{\text {hitung }}$ rewsard $\left(\mathrm{X}_{1}\right)$ sebesar 10.548, disiplin kerja $\left(\mathrm{X}_{2}\right)$ sebesar 5.911 dan komunikasi $\left(\mathrm{X}_{3}\right)$ sebesar 2.256 lebih besar dari nilai $t_{\text {tabel }}$ sebesar 1,664 maka variabel bebas reward, disiplin kerja dan komunikasi berpengaruh signifikan terhadap variabel terikat kepuasan kerja sedangkan variabel reward $\left(\mathrm{X}_{1}\right)$ berpengaruh dominan terhadap kepuasan kerja.
\end{abstract}

Kata Kunci: Reward, Disiplin Kerja, Komunikasi, Kepuasan Kerja.

\begin{abstract}
This research aims to determine the effect of reward, work discipline and communication on job satisfaction at PT. Kerta Rajasa Raya Mojokerto. The type of research used in this study is a quantitative approach. The population in this study were all employees of PT. Kerta Rajasa Raya Mojokerto with a total sample of 83 employees. The sampling technique used is simple random sampling with data collection techniques using a questionnaire. The data analysis technique used is multiple linear regression analysis using the $\mathrm{F}$ test, $\mathrm{T}$ test and dominant test with a significant level of $10 \%$ through the Statistical Package for the Social Science (SPSS). The results of this test indicate that the independent variables, work discipline and communication simultaneously have a significant effect with the results of multiple linear regression in the Fcount test of 50.713 which is greater than Ftable of 2.72 while the partial effect has a significant effect through the t-test for each independent variable. namely tcount reward $\left(\mathrm{X}_{1}\right)$ of 10,548 , work discipline $\left(\mathrm{X}_{2}\right)$ of 5,911 and communication $\left(\mathrm{X}_{3}\right)$ of 2,256 which is greater than the value of ttable of 1,664, the independent variables of reward, discipline and communication have a significant effect on the variable of job satisfaction while the reward variable $\left(\mathrm{X}_{1}\right)$ dominant effect on job satisfaction.
\end{abstract}

Keywords: Reward, Work Discipline, Communication, Job Satisfaction.

*Corresponding Author:

Hal: $34-50$

Email: arisaffandi620@gmail.com 
Memasuki era globalisasi, perusahaan berusaha untuk melaksanakan kegiatan organisasi dengan kualitas yang lebih tinggi serta sumber daya manusia lebih maju dan perusahaan harus siap bersaing dengan perusahaan dari seluruh dunia baik untuk perusahaan manufaktur maupun perusahaan yang bergerak dibidang jasa, karena perusahaan tidak hanya bersaing dengan produk di dalam negeri, tetapi juga harus menghadapi dengan produk luar negeri. Persaingan global yang efektif memerlukan perhatian lebih daripada menghasilkan suatu produk yang akan dijual dipasar, dan mendistribusikannya ke dalam pasar yang baru. Persaingan global yang efektif membutuhkan suatu jaringan kerja yang canggih dan stabil, dimana akan menarik teknologi yang ditemukan dari satu lokasi dan disebarluaskan ke seluruh dunia, seperti kecepatan dari pergerakan produk, manusia, informasi dan ide yang dengan mudah tersebar di seluruh dunia untuk memenuhi kebutuhan, dan manajemen ekonomi baik secara global maupun secara lokal (Suwatno danPriansa, 2018:5).

Fahmi (2017:64)Reward merupakan bentuk pemberian balas jasa yang diberikan kepada seorang karyawan atas prestasi pekerjaan yang dilakukan, baik berbentuk finansial maupun nonfinansial. Busro (2018:315) Reward juga dapat dipahami sebagai bentuk hadiah yang diberikan kepada pegawai yang mampu mendapatkan prestasi tertentu yang bermanfaat bagi perusahaan atau organisasi dalam bentuk finansial maupun nonfinansial dalam rangka meningkatkan semangat, motivasi, komitmen pegawai dan mampu memengaruhi pegawai lain untuk berbuat yang lebih baik, sehingga terjadi persaingan yang positif antar pegawai.

Hamali (2018:214), Disiplin adalah suatu kekuatan yang berkembang di dalam tubuh karyawan dan menyebabkan karyawan dapat menyesuaikan diri dengan sukarela pada keputusan peraturan, dan nilai-nilai tinggi dari pekerjaan dan perilaku. Sutrisno (2016:97) Disiplin menunjukkan suatu kondisi atau sikap hormat yang ada pada diri karyawan terhadap peraturan dan ketetapan perusahaan. Dengan demikian, bila peraturan atau ketetapan yang ada dalam perusahaan itu diabaikan atau sering dilanggar, maka karyawan mempunyai disiplin kerja yang buruk. Sebaliknya, bila karyawan tunduk pada ketetapan perusahaan, menggambarkan adanya kondisi disiplin yang baik.

Hamali (2018:224), komunikasi kerja adalah suatu proses penyampaian ide-ide dan informasi berupa perintah dan petunjuk kerja dari seorang pimpinan kepada karyawan atau para bawahannya untuk melaksanakan tugas-tugas kerja dengan sebaikbaiknya.Handoko (2019:269)Manajemen sering mempunyai masalah tidak efektifnya komunikasi. Padahal komunikasi yang efektif adalah penting bagi para manajer, paling tidak untuk dua alasan. Pertama, komunikasi adalah proses melalui mana fungsi-fungsi manajemen perencanaan, pengorganisasian, pengarahan dan pengawasan dapat dicapai. Kedua, komunikasi adalah kegiatan untuk mana para manajer mencurahkan sebagaian besar proporsi waktu mereka.

Hasibuan (2019), kepuasan kerja adalah sikap emosional yang menye-nangkan dan mencintai pekerjaannya. Sikap ini dicerminkan oleh moral kerja, kedisiplinan, dan prestasi kerja. Kepuasan kerja dinikmati dalam pekerjaan, luar pekerjaan, dan kombinasi dalam dan luar pekerjaan. Hamali (2018), setiap orang yang bekerja mengharapkan dapat memperoleh kepuasan dari tempatnya bekerja. Kepuasan kerja akan memengaruhi produktivitas yang sangat diharapkan oleh seorang manajer, sehingga seorang manajer perlu memahami apa yang harus dilakukan untuk menciptakan kepuasan kerja karyawan. 
Dari uraian diatas penulis tertarik untuk mengadakan penelitian dalam bentuk skripsi dengan judul"Pengaruh Reward, Disiplin Kerja Dan Komunikasi Terhadap Kepuasan Kerja Di PT. Kerta Rajasa Raya Mojokerto”.

\section{TINJAUAN PUSTAKA}

\section{Reward}

Fahmi (2017:64), Reward merupakan bentuk pemberian balas jasa yang diberikan kepada seorang karyawan atas prestasi pekerjaan yang dilakukan, baik berbentuk finansial maupun nonfinansial. Mahmudi dalam Mora dkk., (2019:96), indikator utama sistem reward terdiri atas elemen - elemen, sebagai berikut:

\section{a. Insentif}

Insentif merupakan komponen reward yang sangat penting bagi pegawai dalam hal ini meliputi tambahan kompensasi keuangan berupa bonus dan pemberian saham (stockoption atau stock grant). Reward terhadap kinerja yang tinggi dapat diberikan dalam bentuk pemberian insentif atau pemberian saham kepada pegawai.

b. Kesejahteraan

Kesejahteraan dapat diukur nilainya. Berbagai program kesejahteraan pegawai yang ditawarkan organisasi sebagai bentuk pemberian reward atas presentasi kerja, misalnya: Tunjangan, meliputi tunjangan jabatan, tunjangan struktural, tunjangan kesehatan, tunjungan pendidikan anak, tunjangan keluarga dan tunjangan hari tua. Fasilitas kerja, misalnya kendaraan dinas, sopir pribadi dan rumah dinas. Kesejahteraan rohani, misalnya rekreasi, liburan, paket ibadah dan sebagainya.

\section{c. Pengembangan karir}

Pengembangan karir merupakan prospek kinerja dimasa yang akan datang. pengembangan karir ini penting diberikan bagi pegawai yang memiliki prestasi kerja yang memuaskan agar nilai pegawai itu lebih tinggi sehingga mampu memberikan kinerja yang lebih baik lagi dimasa yang akan datang. pengembangan karir memberikan kesempatan kepada pegawai yang berprestasi untuk belajar dan meningkatkan pengetahuan, keterampilan dan keahliannya.

d. Penghargaan psikologi

Penghargaan psikologi sangat penting nilainya bagi karyawan meskipun sulit diukur. Psikologi yang baik dapat menciptakan semangat dan dapat mempengaruhi kinerja karyawan, penghargaan psikologis meliputi pemberian kepercayaan, pengakuan dan pujian.

\section{Disiplin Kerja}

Hamali (2018:214), disiplin adalah suatu kekuatan yang berkembang di dalam tubuh karyawan dan menyebabkan karyawan dapat menyesuaikan diri dengan sukarela pada keputusan peraturan, dan nilai-nilai tinggi dari pekerjaan dan perilaku.

Hasibuan (2019:194) Pada dasarnya banyak indikator yang mempengaruhi tingkat kedisiplinan karyawan suatu organisasi diantaranya:

a. Tujuan dan kemampuan

Tujuan dan kemampuan ikut mempengaruhi tingkat kedisiplinan karyawan. Tujuan yang akan dicapai harus jelas dan ditetapkan secara ideal serta cukup menantang bagi kemampuan karyawan. Hal ini berarti bahwa tujuan (pekerjaan) yang dibebankan kepada 
karyawan harus sesuai dengan kemampuan karyawan bersangkutan, agar dia bekerja sungguh-sungguh dan disiplin dalam mengerjakannya.

b. Teladan pimpinan

Teladan pimpinan sangat berperan dalam menentukan kedisiplinan karyawan karena pimpinan dijadikan teladan dan panutan oleh para bawahannya. Pimpinan harus memberi contoh yang baik, berdisiplin yang baik, jujur, adil, serta sesuai kata dengan perbuatan. Dengan teladan pimpinan yang baik, kedisiplinan bawahan pun akan ikut baik. Jika teladan pimpinan kurang baik (kurang berdisiplin), para bawahan pun akan kurang disiplin.

c. Balas jasa

Balas jasa (gaji dan kesejahteraan) ikut mempengaruhi kedisiplinan karyawan karena balas jasa akan memberikan kepuasan dan kecintaan karyawan terhadap perusahaan atau pekerjaannya. Jika kecintaan karyawan semakin baik terhadap pekerjaan, kedisiplinan mereka akan semakin baik pula. Untuk mewujudkan kedisiplinan karyawan yang baik, perusahaan harus memberikan balas jasa yang relatif besar, kedisiplinan karyawan tidak mungkin baik apabila balas jasa yang mereka terima kurang memuaskan untuk memenuhi kebutuhan hidupnya beserta keluarga.

\section{d. Keadilan}

Keadilan ikut mendorong terwujudnya kedisiplinan karyawan, karena ego dan sifat manusia yang selalu merasa dirinya penting dan minta diperlakukan sama dengan manusia lainnya. Keadilan yang dijadikan dasar kebijaksanaan dalam pemberian balas jasa (pengakuan) atau hukuman akan merangsang terciptanya kedisiplinan karyawan yang baik.

e. Waskat

Waskat (pengawasan melekat) adalah tindakan nyata dan paling efektif dalam mewujudkan kedisiplinan karyawan perusahan. Dengan waskat berarti atasan harus aktif dan langsung mengawasi perilaku, moral, sikap, gairah kerja, dan prestasi kerja bawahannya. Hal ini berarti atasan harus selalu ada/hadir di tempat kerja agar dapat mengawasi dan memberi petunjuk, jika ada bawahannya yang mengalami kesulitan dalam menyelesaikan pekerjaannya.

f. Sanksi hukuman

Sanksi hukuman berperan penting dalam memelihara kedisiplinan karyawan. Dengan sanksi hukuman yang semakin berat, karyawan akan semakin takut melanggar peraturanperaturan perusahaan, sikap, dan perilaku indisipliner karyawan akan berkurang. Berat/ringannya sanksi hukuman yang akan diterapkan ikut mempengaruhi baik/buruknya kedisiplinan karyawan.

\section{g. Ketegasan}

Ketegasan pimpinan dalam melakukan tindakan akan mempengaruhi kedisiplinan karyawan perusahaan. Pimpinan harus berani dan tegas, bertindak untuk menghukum setiap karyawan yang indisipliner sesuai dengan sanksi hukuman yang telah ditetapkan. Pimpinan yang berani bertindak tegas penerapan hukuman bagi karyawan yang indisipliner akan disegani dan diakui kepemimpinannya oleh bawahan. Ketegasan pimpinan menegur dan menghukum setiap karyawan yang insipliner akan mewujudkan kedisiplinan yang baik pada perusahaan tersebut. 
h. Hubungan kemanusiaan

Hubungan kemanusiaan yang harmonis diantara sesama karyawan ikut menciptakan kedisiplinan yang baik pada suatu perusahaan. Manajer harus berusaha menciptakan suasana hubungan kemanusiaan yang serasi serta mengikat, vertikal maupun horizontal diantara semua karyawannya. Kedisiplinan karyawan akan tercipta apabila hubungan kemanusiaan dalam organisasi tersebut baik.

\section{Komunikasi}

Hamali (2018:224), komunikasi kerja adalah suatu proses penyampaian ide-ide dan informasi berupa perintah dan petunjuk kerja dari seorang pimpinan kepada karyawan atau para bawahannya untuk melaksanakan tugas-tugas kerja dengan sebaik-baiknya. Thoha dalam Maria dan Widiastuti (2019:3) komunikasi dikatakan efektif apabila terpenuhinya indikator-indikator berikut:

a. Keterbukaan

Untuk menunjukan kualitas keterbukaan dari komunikasi antar pribadi paling sedikit ada dua aspek, yakni: aspek keinginan untuk terbuka bagi setiap orang yang berinteraksi dengan orang lain dan Aspek keinginan untuk menanggapi secara jujur.

b. Empati

Yakni mencoba merasakan dengan cara yang sama dengan perasaan orang lain.

c. Dukungan

Dengan dukungan ini akan tercapai komunikasiyang efektif. Dukungan adakalanya terucap dan tidak terucap.

d. Kepositifan

Komunikasi akan berhasil jika terdapat perhatian yang positif terhadap diri seseorang.

e. Kesamaan

Komunikasi akan lebih efektif jika mereka saling mengetahui kesamaan kepribadian diantara mereka.

\section{Kepuasan Kerja}

Hasibuan (2019:202) kepuasan kerja adalah sikap emosional yang menyenangkan dan mencintai pekerjaannya. Sikap ini dicerminkan oleh moral kerja, kedisiplinan, dan prestasi kerja. Kepuasan kerja dinikmati dalam pekerjaan, luar pekerjaan, dan kombinasi dalam dan luar pekerjaan. Sudaryo dkk.,(2018:92) Indikator untuk mengukur kepuasan kerja yaitu sebagai berikut:

a. Kemangkiran

Pegawai yang tinggi tingkat kepuasan kerjanya akan rendah tingkat kemangkirannnya, sebaliknya pegawai yang rendah tingkat kepuasan kerjannya akan cenderung tinggi tingkat kemangkirannya.

b. Keinginan pindah

Tidak dapat disangkal bahwa salah satu faktor penyebab timbulnya keinginan pindah kerja adalah ketidakpuasan di tempat bekerja sekarang. Sebab-sebab ketidakpuasan itu dapat beranekaragam seperti penghasilan rendah atau dirasakan kurang memadai, kondisi kerja yang kurang memuaskan, hubungan yang tidak serasi, baik dengan atasan maupun dengan rekan sekerja, pekerjaan yang tidak sesuai, dan berbagai faktor lainnya. 
c. Kinerja karyawan

Pengertian kinerja adalah hasil kerja secara kualitas dan kuantitas yang dicapai oleh seseorang karyawan dalam kemampuan melaksanakan tugas-tugas sesuai dengan tanggung jawab yang diberikan oleh atasan kepadanya.

d. Rekan kerja

Rekan kerja yang bersahabat, kerja sama rekan sekerja atau kelompok kerja adalah sumber kepuasan kerja bagi pekerja secara individual. Sementara itu kelompok kerja dapat memberikan dukungan, nasehat atau saran kepada sesama rekan kerja. Rekan kerja yaitu teman-teman kepada siapa seseorang senantiasa berinteraksi dalam pelaksanaan pekerjaan. Seseorang dapat merasakan rekan kerja sangan menyenangkan atau tidak menyenangkan.

e. Kenyamanan kerja

Pada umumnya karyawan cenderung lebih senang dengan adanya kondisi lingkungan kantor tempat kerja yang baik dan nyaman, sehingga efisiensi kerja suatu organisasi dapat tercapai dengan baik. Lingkungan kerja atau prasarana fisik yang baik dapat membantu mengurangi kejenuhan dan kelelahan bagi para karyawan.

\section{HIPOTESIS}

Hipotesis dari penelitian ini yaitu sebagai berikut:

a. Bahwa variabel Reward, Disiplin kerja dan Komunikasi secara simultan berpengaruh signifikan terhadap variabel Kepuasan kerja pada PT. Kerta Rajasa Raya Mojokerto.

b. Bahwa variabel Reward, Disiplin kerja dan Komunikasi secara parsial berpengaruh signifikan terhadap variabel Kepuasan Kerja pada PT. Kerta Rajasa Raya Mojokerto.

c. Bahwa variabel Reward berpengaruh dominan terhadap variabel Kepuasan Kerja pada PT. Kerta Rajasa Raya Mojokerto.

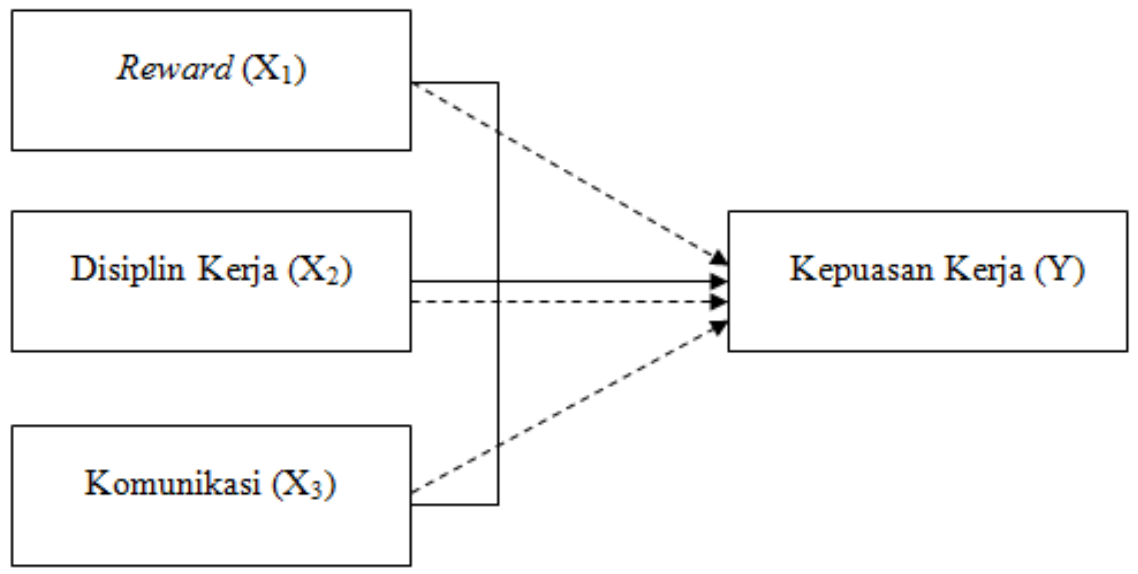

Gambar 1

Kerangka Konseptual 
METODE PENELITIAN

\section{Populasi}

Sugiyono (2016:215) populasi diartikan sebagai wilayah generalisasi yang terdiri atas obyek/subyek yang mempunyai kualitas dan karakteristik tertentu yang ditetapkan oleh peneliti untuk dipelajari dan kemudian ditarik kesimpulannya. Pada penelitian ini, penulis menjadikan karyawan di PT. Kerta Rajasa Raya Mojokerto sebagai populasi yang memiliki jumlah karyawan sebanyak 500 orang.

\section{Sampel}

Sugiyono (2016:215) sampel adalah sebagian dari populasi itu. Sampel ini diambil karena tidak mungkin seluruh populasi di PT. Kerta Rajasa Raya Mojokerto diteliti semua.

\section{Lokasi}

Penelitian dilaksanakan pada PT Kerta Rajasa Raya di Mojosari yang bermain di Industri Manufaktur dengan memperkenalkan produk karung plastik jumbo bag dan woven bag yang beralamatkan Jl. Pemuda No. 01, Rw. 01, Desa Ngrame, Kecamatan Pungging, Kabupaten Mojokerto, Jawa Timur.

\section{Waktu}

Penelitian ini dilakukan sejak Februari tahun 2021 hingga data yang diperlukan sudah lengkap.

\section{Teknik Pengumpulan Data}

Sugiyono (2016:224), teknik pengumpulan data merupakan langkah yang paling strategis dalam penelitian, karena tujuan utama dari penelitian adalah mendapatkan data. Data merupakan faktor terpenting dalam menyusun karya tulis ilmiah, oleh karena itu harus jelas darimana data tersebut diperoleh. Adapun teknik pengumpulan data yang dipakai berasal dari.

\section{Wawancara}

Wawancara digunakan sebagai teknik pengumpulan data apabila peneliti ingin melakukan studi pendahuluan untuk menemukan permasalahan yang harus diteliti, dan juga apabila peneliti ingin mengetahui hal-hal dari responden yang lebih mendalam dan jumlah respondennya sedikit/kecil.

\section{Kuesioner}

Kuesioner merupakan teknik pengumpulan data yang dilakukan dengan cara memberi seperangkat pertanyaan atau pernyataan tertulis kepada responden untuk dijawabnya. Kuesioner merupakan teknik pengumpulan data yang efisien bila peneliti tahu dengan pasti variabel yang akan diukur dan tahu apa yang bisa diharapkan dari responden.

\section{Observasi}

Observasi sebagai teknik pengumpulan data mempunyai ciri yang spesifik bila dibandingkan dengan teknik yang lain, yaitu wawancara dan kuesioner. Kalau wawancara dan kuesioner selalu berkomunikasi dengan orang, maka observasi tidak terbatas pada orang, tetapi juga obyek-obyek alam yang lain. 


\section{Studi Kepustakaan}

Yaitu pengumpulan data skripsi atau penelitian terdahulu dengan cara membaca dokumen-dokumen yang ada hubungannya dengan masalah yang diteliti.

\section{HASIL ANALISIS DAN PEMBAHASAN}

\section{Uji Validitas}

Sugiyono (2016:267), validitas merupakan derajad ketepatan antara data yang terjadi pada obyek penelitian dengan daya yang dapat dilaporkan oleh peneliti. Uji validitas dilakukan dengan mengkorelasikan setiap skor indikator dengan total skor item dalam setiap variabel secara statistik, hasil dari korelasi tersebut dinamakan korelasi product moment ( $\mathrm{r}$ hitung). Bila korelasi tiap indikator positif dan besarnya 0,3 ke atas, maka merupakan konstruk yang kuat. Jadi dapat disimpulkan bahwa instrument tersebut memiliki validitas konstruksi yang baik dan membandingkannya dengan $\mathrm{r}$ tabel didapat dengan menggunakan tabel $\mathrm{r}$ product moment yaitu menentukan $\mathrm{n}$ (sampel) $=83-2=81$ dengan sig $\alpha=0,1$ sehingga didapat $r$ tabel sebesar 0,1818 . Ketentuannya apabila nilai $r$ hitung lebih besar dibanding $\mathrm{r}$ tabel maka indikator atau kuesioner dapat dikatakan valid dengan hasil uji validitas dapat dilihat pada Tabel 1.

Tabel 1

\section{Hasil Uji Validitas}

\begin{tabular}{cccc}
\hline Variabel & Rhitung & Rtabel & Keterangan \\
\hline Reward & & & \\
X1.1 & 0.795 & 0.1818 & Valid \\
X1.2 & 0.876 & 0.1818 & Valid \\
X1.3 & 0.722 & 0.1818 & Valid \\
X1.4 & 0.661 & 0.1818 & Valid \\
Disiplin Kerja & & & \\
X2.1 & 0.570 & 0.1818 & Valid \\
X2.2 & 0.785 & 0.1818 & Valid \\
X2.3 & 0.645 & 0.1818 & Valid \\
X2.4 & 0.604 & 0.1818 & Valid \\
X2.5 & 0.645 & 0.1818 & Valid \\
X2.6 & 0.554 & 0.1818 & Valid \\
X2.7 & 0.530 & 0.1818 & Valid \\
X2.8 & 0.565 & 0.1818 & Valid \\
Komunikasi & & & \\
X3.1 & 0.683 & 0.1818 & Valid \\
X3.2 & 0.801 & 0.1818 & Valid \\
X3.3 & 0.716 & 0.1818 & Valid \\
X3.4 & 0.828 & 0.1818 & Valid \\
X3.5 & 0.680 & 0.1818 & Valid \\
Kepuasan Kerja & & & \\
Y1 & 0.434 & 0.1818 & Valid \\
Y2 & 0.471 & 0.1818 & Valid \\
Y3 & 0.623 & 0.1818 & Valid \\
Y4 & 0.757 & 0.1818 & Valid \\
Y5 & 0.775 & 0.1818 & Valid \\
\hline
\end{tabular}

Sumber : Data diolah peneliti (2021) 
Tabel 1 diatas dapat disimpulkan bahwa semua variabel bebas dan variabel terikat adalah valid dimana nilai $r$ hitung lebih besar daripada nilai $r$ tabel.

\section{Uji Reliabilitas}

Uji reliabilitas merupakan alat untuk mengukur suatu kuesioner yang merupakan indikator dari variabel. Suatu kuesioner dikatakan reliabel atau handal jika jawaban seseorang terhadap pernyataan adalah konsisten atau stabil dari waktu ke waktu. Pengambilan keputusan berdasarkan, jika nilai Alpha melebihi 0,6 maka pernyataan pada indikator variabel tersebut dikatakan reliabel. Adapun hasil dari pengujian reliabilitas dapat dilihat pada Tabel 2.

Berdasarkan Tabel 2 terlihat bahwa variabel bebas yang terdiri dari Reward $\left(\mathrm{X}_{1}\right)$, Disiplin Kerja $\left(\mathrm{X}_{2}\right)$, dan Komunikasi $\left(\mathrm{X}_{3}\right)$ serta variabel terikat Kepuasan Kerja (Y) masing-masing memiliki nilai Alpha Cronboach yang lebih besar dari 0,6. Hal ini menunjukkan bahwa seluruh variabel tersebut adalah reliabel dan dapat digunakan pada analisis selanjutnya.

\section{Analisis Linear Berganda}

Hasil uji analisis linier berganda dalam penelitian dapat dilihat pada Lampiran 1. Berdasarkan Lampiran 1, maka dapat diperoleh persamaan regresi yang terbentuk pada uji regresi ini adalah sebagai berikut:

$\mathrm{Y}=5.501+0,744 \mathrm{X}_{1}+0,190 \mathrm{X}_{2}+0,177 \mathrm{X}_{3}+\mathrm{e}$

\section{Uji Koefisien Determinasi $\mathbf{R}^{2}$}

Hasil analisis regresi berganda pada Lampiran 2 didapatkan nilai koefisien korelasi berganda (R) sebesar 0,811, hal ini menunjukkan bahwa antara variabel bebas dan terikat mempunyai tingkat hubungan dengan kategori sangat kuat. Adapun hasil koefisien determinasin $\left(\mathrm{R}^{2}\right)$ didapatkan sebesar 0,658 atau 65,8\%. Artinya bahwa variabel bebas mempunyai pengaruh terhadap variabel terikat sebesar $65,8 \%$, sedangkan sisanya sebesar $34,2 \%$, dipengaruhi oleh faktor lain yang tidak termasuk dalam variabel penelitian ini.

\section{Uji F (Simultan)}

Hasil pengujian model secara bersama-sama (simultan) pada Lampiran 3 dapat diperoleh nilai $F_{\text {hitung }}$ sebesar 50.713. Nilai ini lebih besar daripada $F_{\text {tabel }}$ sebesar 2,72. Demikian juga nilai signifikan yaitu $\alpha=10 \%$ atau 0,1 . Sehingga dapat disimpulkan bahwa $\mathrm{H}_{0}$ ditolakdan $\mathrm{H}_{1}$ diterima. Artinya variabel Reward, Disiplin Kerja dan Komunikasi secara bersamasama (simultan) memiliki pengaruh signifikan terhadap Kepuasan Kerja (Y) pada PT. Kerta Rajasa Raya Mojokerto.

Tabel 2

Hasil Uji Reliabilitas

\begin{tabular}{ccc}
\hline Variabel & Nilai Alpha & Keterangan \\
\hline$\left(\mathrm{X}_{1}\right)$ & 0,857 & Reliabel \\
$\left(\mathrm{X}_{2}\right)$ & 0,816 & Reliabel \\
$\left(\mathrm{X}_{3}\right)$ & 0,791 & Reliabel \\
$(\mathrm{Y})$ & 0,698 & Reliabel \\
\hline
\end{tabular}

Sumber : Data Diolah Peneliti (2021) 
Dari Lampiran 4 menunjukkan bahwa hasil uji hipotesis yakni (1) Reward memiliki nilai signifikan $0,000>0,1 \quad \mathrm{H}_{0}$ ditolak dan $\mathrm{H}_{1}$ diterima. Hal ini menunjukkan bahwa secara parsial variabel Reward $\left(\mathrm{X}_{1}\right)$ berpengaruh signifikan terhadap Kepuasan Kerja (Y). (2) Disiplin Kerja memiliki nilai signifikan 0,000<0,1 maka $\mathrm{H}_{0}$ ditolak dan $\mathrm{H}_{1}$ diterima. Hal ini menunjukkan bahwa secara parsial variabel Disiplin Kerja $\left(\mathrm{X}_{2}\right)$ berpengaruh signifikan terhadap Kepuasan Kerja (Y). (3) Komunikasi memiliki nilai signifikan signifikan $0,027<0,1$ maka $\mathrm{H}_{0}$ ditolak dan $\mathrm{H}_{1}$ diterima. Hal ini menunjukkan bahwa secara parsial variabel Komunikasi $\left(\mathrm{X}_{3}\right)$ berpengaruh signifikan terhadap Kepuasan $\operatorname{Kerja}(Y)$.

\section{Penentuan Koefisien Dominan}

Dari tiga variabel yang terdiri dari Reward $\left(\mathrm{X}_{1}\right)$, Disiplin Kerja $\left(\mathrm{X}_{2}\right)$, Komunikasi $\left(\mathrm{X}_{3}\right)$, dapat diketahui bahwa variabel Reward $\left(\mathrm{X}_{1}\right)$ mempunyai nilai koefisien $\beta$ (beta) terbesar yaitu 0,705 yang merupakan nilai terbesar diantara variabel-variabel bebas yang lain, sehingga dapat disimpulkan bahwa variabel bebas yang mempunyai pengaruh dominan terhadap variabel terikat Kepuasan Kerja (Y) adalah Reward $\left(\mathrm{X}_{1}\right)$ (Lampiran 5).

\section{PEMBAHASAN}

\section{Uji Hipotesis Pertama Secara Simultan (Uji F)}

Bahwa variabel Reward $\left(\mathrm{X}_{1}\right)$, Disiplin Kerja $\left(\mathrm{X}_{2}\right)$ dan Komunikasi $\left(\mathrm{X}_{3}\right)$ secara bersamasama (simultan) memiliki pengaruh signifikan terhadap Kepuasan Kerja (Y) pada karyawan PT. Kerta Rajasa Raya Mojokerto. Hasil pengujian model secara bersamasama (simultan) diatas diperoleh nilai $\mathrm{F}_{\text {hitung }} 50.713$ sebesar Nilai ini lebih besar daripada $\mathrm{F}_{\text {tabel }}$ sebesar 2,72. Demikian juga nilai signifikan yaitu $\alpha=10 \%$ atau 0,1 . Sehingga dapat disimpulkan bahwa $\mathrm{H}_{0}$ ditolakdan $\mathrm{H}_{1}$ diterima. Artinya variabel Reward $\left(\mathrm{X}_{1}\right)$, Disiplin Kerja $\left(\mathrm{X}_{2}\right)$ dan Komunikasi $\left(\mathrm{X}_{3}\right)$ secara bersama-sama (simultan) memiliki pengaruh yang signifikan terhadap Kepuasan Kerja (Y) pada PT. Kerta Rajasa Raya Mojokerto.

Dalam penelitian ini koefisien korelasi berganda $(\mathrm{R})$ sebesar 0,811 , hal ini menunjukkan bahwa antara variabel bebas dan terikat mempunyai tingkat hubungan dengan kategori sangat kuat. Adapun hasil koefisien determinasi $\left(\mathrm{R}^{2}\right)$ didapatkan sebesar 0,658 atau $65,8 \%$. Artinya bahwa variabel bebas mempunyai pengaruh terhadap variabel terikat sebesar $65,8 \%$, sedangkan sisanya sebesar $34,2 \%$, dipengaruhi oleh faktor lain yang tidak termasuk dalam variabel penelitian ini.Reward $\left(\mathrm{X}_{1}\right)$, Disiplin Kerja $\left(\mathrm{X}_{2}\right)$ dan Komunikasi $\left(\mathrm{X}_{3}\right)$ berpengaruh signifikan terhadap Kepuasan Kerja (Y). Adanya Reward akan membuat karyawan lebih produktif dan memiliki kepuasan kerja yang tinggi, Disiplin yang baik mencerminkan besarnya tanggung jawab karyawan terhadap tugastugas yang diberikan kepadanya, Serta adanya komunikasi yang baik tercipta rasa puas bagi karyawan, maka diharapkan Kepuasan Kerja di PT. Kerta Rajasa Raya Mojokerto akan meningkat.

\section{Uji Hipotesis Kedua Secara Parsial (Uji T) Pengaruh Reward terhadap Kepuasan Kerja}

Berdasarkan hasil penelitian pengujian secara parsial dengan uji t untuk mengetahui pengaruh Reward terhadap Kepuasan Kerja diperoleh bahwa nilai $t_{\text {hitung }} \geq t_{\text {tabel }}$ dan nilai signifikansi yang dihasilkan sebesar 0,000 yang lebih kecil dari 0,1, maka $\mathrm{H}_{0}$ ditolak dan 
$\mathrm{H}_{1}$ diterima. Artinya variabel Reward secara parsial memiliki pengaruh yang signifikan terhadap Kepuasan Kerja pada PT. Kerta Rajasa Raya Mojokerto.

Hal ini menunjukkan bahwa Reward pada PT. Kerta Rajasa Raya Mojokerto yang diberikan pada karyawan yang berprestasi akan menimbulkan kepuasan pada diri karyawan sehingga akan membuat karyawan lebih produktif dan memiliki semangat kerja yang tinggi. Hal ini sesuai dengan teori yang dikemukakan oleh Fahmi (2017:64) reward merupakan bentuk pemberian balas jasa yang diberikan kepada seorang karyawan atas prestasi pekerjaan yang dilakukan, baik berbentuk finansial maupun non finansial. Hasil penelitian ini didukung hasil penelitian sebelumnya yang dilakukan oleh Aini (2020) yang menyatakan bahwa variabel Reward secara parsial berpengaruh signifikan terhadap Kepuasan Kerja.

\section{Pengaruh Disiplin Kerja terhadap Kepuasan Kerja}

Berdasarkan hasil penelitianpengujian secara parsial dengan uji $\mathrm{t}$ untuk mengetahui pengaruh Disiplin Kerja terhadap Kepuasan Kerja diperoleh bahwa nilai $t_{\text {hitung }} \geq t_{\text {tabel }}$ dan nilai signifikansi yang dihasilkan sebesar 0,000 yang lebih kecil dari 0,1, maka $\mathrm{H}_{0}$ ditolak dan $\mathrm{H}_{1}$ diterima. Artinya variabel Disiplin Kerja secara parsial memiliki pengaruh yang signifikan terhadap Kepuasan Kerja pada PT. Kerta Rajasa Raya Mojokerto.

Hal ini menunjukkan bahwa Disiplin Kerja di PT. Kerta Rajasa Raya Mojokerto yang tinggi berupa pemberian sanksi surat peringatan akan membuat karyawan bertanggung jawab atas pekerjaannya dan meningkatkan kepuasan kerja. Dengan adanya sikap disiplin yang tercipta didalam diri karyawan, karyawan dapat bekerja sesuai dengan peraturan yang telah ditetapkan pada PT. Kerta Rajasa Raya Mojokerto sehingga dengan begitu karyawan akan merasa puas terhadap keadilan yang sama pada perusahaan. Hal ini sesuai dengan teori yang dikemukakan oleh Hamali (2018:214), disiplin adalah suatu kekuatan yang berkembang di dalam tubuh karyawan dan menyebabkan karyawan dapat menyesuaikan diri dengan sukarela pada keputusan peraturan, dan nilai-nilai tinggi dari pekerjaan dan perilaku.Hasil penelitian ini didukung hasil dari penelitian sebelumnya yang dilakukan oleh Saputra (2018) yang menyatakan bahwa variabel Disiplin Kerja secara parsial berpengaruh signifikan terhadap Kepuasan Kerja.

\section{Pengaruh Komunikasi terhadap Kepuasan Kerja}

Berdasarkan hasil penelitianpengujian secara parsial dengan uji $t$ untuk mengetahui pengaruh Komunikasi terhadap Kepuasan Kerja diperoleh bahwa nilai $t_{\text {hitung }} \geq t_{\text {tabel }}$ dan nilai signifikansi yang dihasilkan sebesar 0,027 yang lebih kecil dari 0,1, maka $\mathrm{H}_{0}$ ditolak dan $\mathrm{H}_{1}$ diterima. Artinya variabel Komunikasi secara parsial memiliki pengaruh yang signifikan terhadap Kepuasan Kerja pada PT. Kerta Rajasa Raya Mojokerto.

Hal ini menunjukkan bahwa Komunikasi yang efektif di PT. Kerta Rajasa Raya Mojokerto mendorong kepuasan kerja yang lebih baik. Adanya komunikasi yang baik tercipta rasa puas bagi karyawan. Dengan begitu semakin baik komunikasi yang terjalin pada karyawan maka kepuasan kerjanya akan meningkat pula. Hal ini sesuai dengan teori yang dikemukakan oleh Hamali (2018:224), komunikasi kerja adalah suatu proses penyampaian ide-ide dan informasi berupa perintah dan petunjuk kerja dari seorang pimpinan kepada karyawan atau para bawahannya untuk melaksanakan tugas-tugas kerja dengan sebaik-baiknya. Hasil penelitian ini didukung hasil dari penelitian sebelumnya 
yang dilakukan oleh Vionna (2020) yang menyatakan bahwa variabel Komunikasi secara parsial berpengaruh signifikan terhadap Kepuasan Kerja.

\section{Pengaruh Dominan}

Dari tiga variabel yang terdiri dari Reward $\left(\mathrm{X}_{1}\right)$, Disiplin Kerja $\left(\mathrm{X}_{2}\right)$ dan Komunikasi $\left(\mathrm{X}_{3}\right)$, dapat diketahui bahwa variabel Reward $\left(\mathrm{X}_{1}\right)$ mempunyai nilai koefisien $\beta$ (beta) yaitu 0,705 yang merupakan nilai terbesar diantara variabel-variabel bebas lain. Sehingga dapat disimpulkan bahwa variabel bebas yang mempunyai pengaruh dominan terhadap variabel terikat Kepuasan Kerja adalah variabel Reward $\left(\mathrm{X}_{1}\right)$. Reward adalah suatu pemberian balas jasa kepada karyawan berprestasi yang bermanfaat bagi organisasi atau perusahaan atas kerja keras karyawan dalam bentuk finansial maupun nonfinansial, sehingga adanya pemberian Reward bagi karyawan berprestasi maka akan tercipta adanya rasa puas. Hasil penelitian ini didukung hasil dari penelitian sebelumnya yang dilakukan oleh Aini (2020) yang menyatakan bahwa adanya pemberian Reward atau penghargaan dari perusahaan kepada karyawan menjadi salah satu hal yang dapat meningkatkan Kepuasan Kerja didalam perusahaan itu sendiri.

\section{SIMPULAN DAN SARAN}

Berdasarkan hasil penelitian dan pembahasan yang digunakan sesuai dengan hipotesis yang dilakukan dengan menggunakan analisis regresi berganda, maka dapat ditarik simpulan adalah: (1) Reward, Disiplin Kerja dan Komunikasi secara simultan berpengaruh positif dan signifikan terhadap Kepuasan Kerja di PT. Kerta Rajasa Raya Mojokerto. Pengujian hipotesis penelitian dilakukan dengan menggunakan uji-F, dimana hasil pengujian diperoleh nilai signifikan $<0,1$. Dan dari hasil pengujian tersebut menunjukkan bahwa hipotesis diterima dan terbukti kebenarannya. Penelitian menyatakan bahwa Reward, Disiplin Kerja dan Komunikasi berpengaruh secara simultan dan signifikan terhadap Kepuasan Kerja. (2) Reward, Disiplin Kerja dan Komunikasi secara parsial berpengaruh positif dan signifikan terhadap Kepuasan Kerja di PT. Kerta Rajasa Raya Mojokerto. Pengujian hipotesis penelitian dilakukan dengan menggunakan uji-t, dimana hasil pengujian diperoleh nilai signifikan $<0,1$. Dan dari hasil pengujian tersebut menunjukkan bahwa hipotesis diterima dan terbukti kebenarannya. Penelitian menyatakan bahwa Reward, Disiplin Kerja dan Komunikasi berpengaruh secara parsial dan signifikan terhadap Kepuasan Kerja. (3) Reward mempunyai pengaruh dominan terhadap Kepuasan Kerja di PT. Kerta Rajasa Raya Mojokerto. Hasil diperoleh dari pengujian menggunakan uji-dominan, dimana nilai Standardized Coefficients variabel Reward lebih besar dari variabel Disiplin Kerja dan Komunikasi. Saran bagi perusahaan bahwa variabel Reward, Disiplin Kerja dan Komunikasi mempunyai pengaruh signifikan secara simultan terhadap Kepuasan Kerja di PT. Kerta Rajasa Raya Mojokerto. Oleh sebab itu, faktor Reward, Disiplin Kerja dan Komunikasi sangat penting bagi perusahaan untuk diperhatikan demi meningkatkan Kepuasan Kerja karyawan. Jadi jika perusahaan ingin meningkatkan Kepuasan Kerja karyawan, maka perusahaan sebaiknya lebih memperhatikan variabel Reward, Disiplin Kerja dan Komunikasi. Saran bagi karyawan, dimana karyawan PT. Kerta Rajasa Raya Mojokerto diharapkan dapat menyelesaikan target yang telah ditetapkan oleh perusahaan, mematuhi peraturan yang ditetapkan oleh perusahaan seperti datang tepat waktu, tidak bermain gadget saat jam kerja dan tidak merokok disaat jam kerja berlangsung, serta dapat mengikuti kegiatan briefing, gathering 
dan kegiatan perkumpulan lainnya sehingga terjalin komunikasi yang efektif dengan begitu akan tercipta rasa puas atau kepuasan kerja karyawan di PT. Kerta Rajasa Raya Mojokerto. Saran bagi peneliti selanjutnya diharapkan dapat mempertimbangkan serta megembangkan variabel bebas lainnya yang mempengaruhi kepuasan kerja yang tidak diteliti dalam penelitian ini. Diharapkan untuk menerapkan penelitian dengan cakupan lain ataupun yang lebih luas yaitu seperti mencari lokasi penelitian selain PT. Kerta Rajasa Raya Mojokerto.

\section{DAFTAR PUSTAKA}

Ajabar. (2020). Manajemen Sumber Daya Manusia (Cetakan Pe). Yogyakarta: Deepublish.

Busro. (2018). Teori-teori Manajemen Sumber Daya Manusia (Edisi Pert). Jakarta: prenada media group.

Duha. (2018). Perilaku Organisasi (Edisi pert). Yogyakarta: Deepublish.

Edison dkk. (2018). Manajemen Sumber Daya Manusia, Strategidan Perubahan dalam Rangka Meningkatkan Kinerja Pegawai dan Organisasi (Cetakan ke). Alfabeta.

Fahmi. (2017). Manajemen Sumber Daya Manusia Teori dan Aplikasi (Cetakan ke). Bandung: Alfabeta.

Faida. (2019). Manajemen Sumber Daya Manusia dan Ekonomi Unit Kerja Rekam Medis (Edisi Pert). Sidoarjo: Indomedia Pustaka.

Ghozali. (2016). Aplikasi Analisis Multivarite dengan Program IBM SPSS 25. UNDIP.

Hamali. (2018). Pemahaman Manajemen Sumber Daya Manusia Strategi Mengelola Karyawan (Cetakan ke). Jakarta: PT BUKU SERU.

Handoko. (2019). Manajemen (Edisi Kedu). Yogyakarta: BPFE YOGYAKARTA.

Hasibuan. (2019). Manajemen Sumber Daya Manusia (Edisi Revi). Jakarta: Bumi Aksara.

Indriyantoro dan Supomo. (2016). Metodologi Penelitian Bisnis untuk Akuntansi dan Manajemen (Edisi Pert). Yogyakarta: BPFE YOGYAKARTA.

Jaya. (2020). Metode Penelitian Kuantitatif dan Kualitatif, Teori, penerapan, dan Riset Nyata (Cetakan Pe). Yogyakarta: QUADRANT.

Maria dan Widiastuti. (2019). Pengaruh Pembagian Kerja dan Komunikasi terhadap Stres Kerja Karyawan pada PT. Perdana Jaya Tunggal Perkasa Denpasar. Majalah Ilmiah Widayacakra, 2. 
Mora dkk. (2019). Reward dan Kompensasi serta Pangaruhnya Terhadap Kinerja Karyawan Bank BRI Cabang Langsa. Jurnal Samudra Ekonomika, 3.

Permatasari dkk. (2015). Pengaruh Disiplin Kerja dan Motivasi Kerja terhadap Prestasi Kerja Karyawan (Studi pada PT BPR Gunung Ringgit Malang). Jurnal Administrasi Bisnis, 25.

Rezi dan Nufus. (2017). Hubungan Kemampuan Pemecahan Masalah Matematis dengan Kemampuan Komunikasi Matematis Siswa. THEOREMS, 1, 88.

Riinawati. (2019). Pengantar Teori Manajemen Komunikasi dan Organisasi. Yogyakarta: PT Pustaka Baru.

Saputra dan Turnip. (2018). Pengaruh Motivasi, Komunikasi dan Disiplin terhadap Kepuasan Kerja PT PLN (Persero) P3B SUMBAGUT. Jurnal Manajemen Bisnis STIE IBBI, 29.

Sinambela. (2018). Manajemen Sumber Daya Manusia, Membangun Tim Kerja yang Solid untuk Meningkatkan Kinerja (Cetakan ke). Jakarta: Bumi Aksara.

Sopiah dan Sangaji. (2018). Manajemen Sumber Daya Manusia Strategik (Edisi Pert). Yogyakarta: ANDI OFFSET.

Sudaryo dkk. (2018). Manajemen Sumber Daya Manusia, Kompensasi Tidak Langsung dan Lingkungan Kerja Fisik (Edisi pert). Yogyakarta: Andi (anggota IKAPI).

Sugiyono. (2016). Metode Penelitian Kuantitatif, Kualitatif dan R \& D (Cetakan ke). Bandung: Alfabeta.

Sugiyono. (2019). Metode Penelitian Kuantitatif Kualitatif (Edisi Kedu). Bandung: Alfabeta.

Suharyadi dan Purwanto, (2016). Statistika unutk Ekonomi Keuangan dan Keuangan Modern (3rd ed; dedy, ed.). Jakarta: Salemba Empat.

Sukrispiyanto. (2019). Manajemen Sumber Daya Manusia (Edisi Pert). Sidoarjo: Indomedia Pustaka.

Sutrisno. (2016). Manajemen Sumber Daya Manusia (Edisi Pert). Jakarta: prenadamedia group.

Suwatno dan Priansa. (2018). Manajemen SDM Dalam Organisasi Publik Dan Bisnis (cetakan ke). Bandung: Alfabeta. 
Thoha. (2016). Perilaku Organisasi Konsep Dasar dan Aplikasinya (Edisi ke 2). Depok: PT Raja grafindo Persada.

Umam. (2018). Perilaku Organisasi (Cetakan ke). Bandung: CV. Pustaka Setia.

Usman. (2016). Manajemen Teori, Praktik, dan Riset Pendidikan (Edisi keem). Jakarta: Bumi Aksara.

Vionna dan Budiyanto. (2020). Pengaruh Motivasi, Komunikasi dan Stress Kerja Terhadap Kepuasan Kerja Karyawan pada Bogasari Baking Center Surabaya. Jurnal Ilmu dan Riset Manajemen, 9. 
Lampiran 1. Model Persamaan Regresi

\begin{tabular}{|c|c|c|c|c|c|c|}
\hline & & \multicolumn{3}{|c|}{ Coefficients } & & \\
\hline \multirow{2}{*}{\multicolumn{2}{|c|}{ Madel }} & \multicolumn{2}{|c|}{ Unstandardized Coefficients } & \multirow{2}{*}{$\begin{array}{c}\begin{array}{c}\text { Standardized } \\
\text { Coefficients }\end{array} \\
\text { Beta }\end{array}$} & \multirow[b]{2}{*}{ t } & \multirow[b]{2}{*}{ Sig. } \\
\hline & & $\mathbf{B}$ & Std. Error & & & \\
\hline 1 & (Constant) & 5.501 & 1.716 & & 3.205 & .002 \\
\hline & Reward & .744 & .070 & .705 & 10.548 & .000 \\
\hline & Disiplin Kerja & .190 & .032 & .395 & 5.911 & .000 \\
\hline & Komunikasi & .177 & .078 & .153 & 2.256 & .027 \\
\hline
\end{tabular}

a. Dependent Variable: Kepuasan Kerja

Sumber: Data diolah peneliti (2021)

\section{Lampiran 2. Koefesien Korelasi dan Determinasi}

\section{Model Summary}

\begin{tabular}{|c|c|r|r|c|}
\hline Model & $\mathrm{R}$ & $\mathrm{R}$ Square & $\begin{array}{c}\text { Adjusted R } \\
\text { Square }\end{array}$ & $\begin{array}{c}\text { Std. Error of } \\
\text { the Estimate }\end{array}$ \\
\hline 1 & $.811^{\mathrm{a}}$ & .658 & .645 & 1.661 \\
\hline
\end{tabular}

a. Predictors: (Constant), Komunikasi, Reward, Disiplin Kerja

Sumber: Data Diolah Peneliti (2021)

\section{Lampiran 3. Hasil Uji F (Simultan)}

ANOVA

\begin{tabular}{|ll|r|r|r|r|r|}
\hline Model & \multicolumn{1}{|c|}{$\begin{array}{c}\text { Sum of } \\
\text { Squares }\end{array}$} & df & Mean Square & F & Sig. \\
\hline 1 & Regression & 419.813 & 3 & 139.938 & 50.713 & $.000^{a}$ \\
& Residual & 217.994 & 79 & 2.759 & & \\
& Total & 637.807 & 82 & & & \\
\end{tabular}

a. Predictors: (Constant), Komunikasi, Reward, Disiplin Kerja

b. Dependent Variable: Kepuasan Kerja

Sumber: Data Diolah Peneliti (2021)

Lampiran 4. Hasil Uji T (Parsial)

Coefficients

\begin{tabular}{|ll|r|r|r|r|r|}
\hline \multicolumn{2}{|l|}{} & \multicolumn{2}{|c|}{ Unstandardized Coefficients } & \multicolumn{2}{c|}{$\begin{array}{c}\text { Standardized } \\
\text { Coefficients }\end{array}$} & \\
\cline { 3 - 5 } & & \multicolumn{1}{|c|}{$\mathrm{B}$} & \multicolumn{1}{|c|}{ Std. Error } & \multicolumn{1}{c|}{ Beta } & \multicolumn{1}{c|}{ Sig. } \\
\hline 1 & (Constant) & 5.501 & 1.716 & & 3.205 & .002 \\
& Reward & .744 & .070 & .705 & 10.548 & .000 \\
& Disiplin Kerja & .190 & .032 & .395 & 5.911 & .000 \\
& Komunikasi & .177 & .078 & .153 & 2.256 & .027 \\
\hline
\end{tabular}

a. Dependent Variable: Kepuasan Kerja

Sumber : Data Diolah Peneliti (2021) 
Lampiran 5. Hasil Penentuan Koefisien Dominan

Coefficients ${ }^{2}$

\begin{tabular}{|c|c|c|c|c|c|c|}
\hline \multirow{2}{*}{\multicolumn{2}{|c|}{ Model }} & \multicolumn{2}{|c|}{ Unstandardized Coefficients } & \multirow{2}{*}{$\begin{array}{c}\begin{array}{c}\text { Standardized } \\
\text { Coefficients }\end{array} \\
\text { Beta }\end{array}$} & \multirow[b]{2}{*}{$t$} & \multirow[b]{2}{*}{ Sig. } \\
\hline & & B & Std. Error & & & \\
\hline \multirow[t]{4}{*}{1} & (Constant) & 5.501 & 1.716 & & 3.205 & .002 \\
\hline & Reward & .744 & .070 & .705 & 10.548 & .000 \\
\hline & Disiplin Kerja & .190 & .032 & .395 & 5.911 & .000 \\
\hline & Komunikasi & .177 & .078 & .153 & 2.256 & .027 \\
\hline
\end{tabular}

a. Dependent Variable: Kepuasan Kerja

Sumber : Data Diolah Peneliti (2021) 